\title{
The Role of Iran in Yemen Conflict 2014-2018 (An Analysis Of Constructivism)
}

\author{
Riskiansyah Ramadhan \\ \{riskiansyah.ramadhan08@gmail.com\} \\ School of Strategic and Global Studies, Universitas Indonesia, Jakarta, Indonesia
}

\begin{abstract}
The conflict in Yemen, which is a power competition between local tribes and the government to gain control over the country, has been internationalized by the involvement of external powers. Saudi Arabia's led coalition intervention in early 2015, which aimed to diminish the Houthi rebels, has worsened the conflict. Furthermore, the conflict has become the field of proxy between Saudi and Iran. Using the constructivism theory of Alexander Wendt, this paper aims to analyze the factors that attract Iran to get involved in Yemen conflict by supporting the Houthi. The type of research is analytical descriptive, using a qualitative approach. The study concludes that Shiism, antiimperialism, both against the US and Israel, and anti-Wahhabism are factors that attract Iran to support the Houthi. Besides, Iran's involvement in Yemen is also in the context of achieving its national interests in the form of political and ideological interests.
\end{abstract}

Keywords: Conflict, Houthi, Interest, Iran, Yemen

\section{Introduction}

The resignation of President Ali Abdullah Saleh in June 2011 marked the prolonged conflict in Yemen. The presence of al-Qaeda and the riots that almost claimed his life prompted the United States to persuade Saleh to transfer authority to his deputy, Abd Rabbu Mansour Hadi. ${ }^{1}$ Saleh's resignation marked the transfer of power to Vice President Abd Rabbu Mansour Hadi. The gulf states consisting of Bahrain, Kuwait, Qatar, Saudi Arabia, and the United Arab Emirates, initiated the transfer of power.

After the transition, Yemen held a general election to elect a president. In the poll, Abd Rabbu Mansour Hadi was the only candidate in the 2012 election. However, his election as president received opposition from several opposition groups, such as separatist movements in southern Yemen and Houthi rebels. Houthis are a revivalist movement of Shiite Zaidiyah that seeks to seize power. In its fight against the government, the Houthis were supported by Iran with financial assistance, weapons, and military training. Besides, the Iranian Revolutionary Guard Corps (IRGC) was also found to be involved in providing training and assistance services to the Houthis in Sa'adah province.

Since the involvement of external parties, the conflict in Yemen has now transformed into an international conflict. Saudi involvement and the coalition, which was initially intended to restore the government of President Hadi, has now turned into a proxy field for two major powers in the Middle East, Saudi, and Iran. The Saudis believe that the Houthis pose a threat to

${ }^{1}$ Tilly, C., \& Sidney Tarrow. Contentious Politics. New York: Oxford University Press, 2015. p. 137 
the security of their territory concerning the group's relations with Iran. The narration that the Houthis are puppets for Iran expressed by the Yemeni and Saudi governments seems to delegitimize the movement. ${ }^{2}$ According to the Saudis, Iran is trying to undermine Yemen's security and stability that has sparked divisions. Besides, Iran is also believed to be trying to thwart international efforts to achieve conflict resolution in Yemen. ${ }^{3}$

The relationship between Iran and non-state actors is satisfying to discuss given Iran's pragmatism, which tends to establish relations with non-state actors. According to Thomas Juneau (2011), Iran does not build alliances with non-state-based ideological actors, but with consideration of how much profit Iran will achieve. However, in the case of Yemen, several dominant groups have the potential to ally with Iran. However, Iran prefers to support Houthis over other groups such as ISIS, AQAP, and Southern Movement (SM). Factors that attract Iran to help the Houthis are interesting to discuss, which in this case, Iran uses an ideological basis as an entity to gain interest in Yemen.

The researchers have widely analyzed the phenomenon that occurs between Iran and Houthi using the view of realism that emphasizes material aspects, such as the balance of power, national interest, and so forth. This fact is contrary to the view of constructivism, which concerned more with ideas and understanding than material. In this perspective, the interests of an actor having a purpose are built through concepts that are understood together. The similarity in seeing these ideas, or known as intersubjective meanings that are interpreted together, ultimately shapes the identity and determines the interests of each actor. To the relations between Iran and Houthi, an analysis of the factors underlying the close ties between the two actors needs more attention. Thus, it can be seen that there is a social construction process that lies behind Iran and Houthi's interests in the Yemeni conflict.

\section{Theory}

To analyze the relationship between Iran and Houthi, the author uses the theory of constructivism. Constructivism emphasizes the construction of social reality. Human relations, including international relations, basically consist of thoughts and ideas that are not material conditions or forces. So, to view national power and interests, materialist and ideational views are, of course, different. In the materialist view, national power and interests are seen as material factors. Material factors are objective entities in the sense that because the state of anarchy is encouraged to pay attention to power and interests. In this view, ideas are not very important and can only be used to rationalize actions dictated by material power and interests. Whereas in the ideational view, ideas are essential in the form of intersubjective beliefs that are understood by the actors. These ideas not only apply to state actors, but can also be held by different groups, such as organizations, policymakers, social groups, and the general public. ${ }^{4}$

In the view of constructivism, increased relations or interactions between actors are marked by speech acts made by these actors. The statement of action is a sign that an actor will take a step or make another actor act in the same corridor, eventually creating a set of rules or equality

\footnotetext{
${ }^{2}$ Maria-Louise Clausen. Understanding the Crisis in Yemen : Evaluatin Competing Narratives. Italian Journal of International Affairs, 2015. p. 20

${ }^{3}$ Embassy of Kingdom of Saudi Arabia. Saudi Arabia Condems Ongoing Iranian Regional Interference and Agression. Retrieved from Embassy of KSA: http://ksaembassy.be/en/saudi-arabia-condemnsongoing-iranian-regional-interference-aggression/ November 9, 2016

${ }^{4}$ Robert H. Jackson and Georg Sørensen. Pengantar Studi Hubungan Internasional. (Terj. D. Suryadipura, \& Pancasari Suyatiman), Yogyakarta: Pustaka Pelajar, 2014. p. 369-372
} 
of intersubjectivity that is mutually agreed upon to be carried out. With similarities in intersubjectivity, the practice or interaction has a central position. Without interaction, structures will not be formed and exist. A group of actors with the same intersubjectivity, without interaction either through motion, words, or other communication symbols, will not build anything. But when interactive communication between actors takes place, patterns or structures in social relationships are formed. However, when a structure is created through the interaction between actors, the structure turns around, influencing the subjects of the creator who are none other than the actors themselves. The structure is transformed into a kind of rules (norms) for the actors to carry out their interactions. In other words, the interaction process gives birth to knowledge in identifying who is a friend and who is the opponent. This knowledge eventually becomes the basis and normative guidance for each actor to carry out social activities. ${ }^{5}$

\section{Methodology}

This research is an analytical descriptive study using a qualitative approach. The data obtained are secondary data collected through sources that are directly related to the research theme, even though the information does not come from the primary source, but only from other parties. In this study, secondary data sources were obtained through scientific publications in the form of books, journals, theses, doctoral dissertations, scientific articles, and print and online media, as well as other sources relevant to the research topic. Besides, the authors also use essential documents such as foreign policy, laws, reports, surveys, and other materials both in print and online to support and complete the primary data used in research.

\section{Result and Analysis}

In contrast to the Saudi, who more often build alliances with other countries in the Middle East, especially with the GCC countries and the Arab League, Iran tends to use non-state actors as alliances. This fact can be seen from Iran's supports to non-state actors in the Middle East, such as Hamas and Islamic Jihad in Palestine, Hezbollah in Lebanon, Asa'ib Ahl al-Haq in Iraq, and so on. Besides, in building alliances with non-state actors, Iran tends to be pragmatic by supporting every actor in a country, then eliminating and choosing the most influential and most loyal.

As for the connection with Yemen, in this country, several dominant terrorist groups have been a threat to political stability there. According to data compiled by the Global Terrorism Index published in 2018, Yemen ranks eighth as the country most affected by terrorism in the world. The number of deaths in Yemen, according to data obtained, reached around $41 \%$ between 2015-2016. Despite the decline of the death toll caused by terrorism, the current situation in Yemen is exacerbated by the outbreak of conflict with the involvement of external parties. The most active and dominant groups in Yemen are Houthis or Ansar Allah. They were then followed by AQAP or Ansari Sharia, and ISIS.

The Houthis have transformed into the deadliest group since 2015, defeating AQAP. This phenomenon is inseparable from the role of Iran, which has been supporting Houthi, both

${ }^{5}$ Cecep Zakaria El-Bilad. Konstruktivisme Hubungan Internasional: Meretas Jalan Damai Perdebatan Antarparadigma. EJournal UMM, 2012. p. 70 
through funding and military training. Houthis are active in the Taiz and Ma'rib regions, AQAP in the Abyan and Lahij regions, while ISIS is in the south coast region of Aden. When viewed from the standpoint of rivalry with the Saudis, the US, and Israel, these groups have the potential to become an Iranian alliance. Despite the similarity of the common enemy, Iran prefers to support and build an alliance with the Houthis.

According to Thomas Juneau (2016), Iran does not base its support on certain actors based on shiism. A group must only oppose the status quo, which is dominated by the US and its allies, especially Israel and Saudi, to get help from Iran. This fact can be seen from Iran's support for Hamas and Islamic Jihad in Palestine, which are Israel's primary opponents. In fact, according to several sources, Iran also assists, albeit limited, Taliban groups in Afghanistan. Besides, Iran also conducts natural selection in building alliances by supporting groups in a country and choosing the most loyal and most influential.

However, according to the author, Iran considers Shi'ite ideology similarity in its efforts to build an alliance with the Houthis. As briefly reviewed, that in Yemen, several dominant groups are competing for power, including ISIS, AQAP, SM, and Houthi. However, among the groups that exist, Iran prefers to build an alliance with Houthis, and not with other groups. Referring to some literature, if the indicator used to find out the relationship between Iran and the groups supported is anti-imperialism, ISIS, AQAP, and Houthi are included in the ideal group category for Iran to build an alliance. If analyzed through the strengths of each group, then basically AQAP is the most powerful, considering this group is the wealthiest and most deadly groups when compared to other al-Qaeda affiliation groups in various countries.

Table 1. Indicators of loyalty and alliance

\begin{tabular}{ccccc}
\hline Groups & $\begin{array}{c}\text { Anti-United } \\
\text { States of } \\
\text { America }\end{array}$ & $\begin{array}{c}\text { Anti- } \\
\text { Israel }\end{array}$ & Shi'ism & $\begin{array}{c}\text { Recognizing } \\
\text { Wilayat } \\
\text { Faqih }\end{array}$ \\
\hline Hezbollah & $\sqrt{ }$ & $\sqrt{ }$ & $\sqrt{ }$ & $\sqrt{ }$ \\
Houthi & $\sqrt{ }$ & $\sqrt{ }$ & $\sqrt{ }$ & - \\
AQAP & $\sqrt{ }$ & $\sqrt{ }$ & - & - \\
ISIS-Y & $\sqrt{ }$ & $\sqrt{ }$ & - & - \\
Southern Movement & - & - & - & - \\
\hline
\end{tabular}

In my opinion, the only factor that distinguishes Houthis from other groups, and is a consideration of Iran in the effort to build an alliance is a factor of Shiism, even though the Shiites embraced by the Houthis are the Shia Zaidiyah. However, in the Shia Zaidiyah, several sub-sects have different views, among others, namely al-Bitriyyah or al-Salihiyyah, alSulaimaniyyah, and al-Jarudiyyah. Husein al-Houthi is a follower of the al-Jarudiyyah sub-sect founded by Abu al-Jarud, who has the original name Ziyad ibn Abi Al-Mundhir. According to Ahmad ibn Abd al-Aziz al-Hussain (2007), although al-Jarudiyyah claimed his group as Shia Zaidiyah, this group was Shia Ghulat or Rafidhah who did not recognize the validity of Abu Bakar al-Shiddiq, Umar ibn al-Khattab, and Utsman ibn Affan as Caliphates other than Caliph Ali ibn Abi Talib. This fact shows that although the Shia Zaidiyah has been known to be closer 
to the Sunnis, in the case of the Houthis, who are followers of the al-Jarudiyyah sub-sect, it is closer to the Shia Imamiyah. ${ }^{6}$

The funding provided by Iran for the Houthis shows the close relations between Iran and Houthi. Research conducted by The Soufan Center shows the number of funds disbursed by Iran to several countries and militias in the Middle East. The details in table 2 below show that Syria is estimated to receive funds of 6 billion dollar every year. The funding is used for economic assistance, oil subsidies, commodity transfers, and military assistance. Iraq received 1 billion dollar, in which the majority of the money was used to fund militias there. Lebanon, which is the center of Hezbollah, earns around \$ 700 million. As for Palestine and Yemen, each received 100 million dollar, which was used to fund the militias allied with Iran. In addition to the Middle East, Iran also disbursed funds of around 2 million dollar for militias in Afghanistan.

Table 2. Funding from Iran for countries/militias in the Middle East

\begin{tabular}{|c|c|c|c|}
\hline No & Countries & Militias & Fund \\
\hline 1 & Syria & $\begin{array}{l}\text { Basji } \\
\text { IRGC } \\
\text { National Defense Force } \\
\text { Hezbollah } \\
\text { Liwa Fatemiyoun } \\
\text { Liwa Zainebiyoun }\end{array}$ & $\$ 6$ bn \\
\hline 2 & Iraq & $\begin{array}{l}\text { Harakat al-Nujaba } \\
\text { Asa'ib Ahl al-Haq } \\
\text { Badr Organization } \\
\text { Kata'ib Hezbollah }\end{array}$ & $\$ 1$ bn \\
\hline 3 & Lebanon & $\begin{array}{l}\text { Hezbollah } \\
\text { Palestine Islamic Jihad }\end{array}$ & $\$ 700 \mathrm{~m}$ \\
\hline 4 & Palestine & $\begin{array}{l}\text { Al-Aqsa Martyr's Brigade } \\
\text { Hamas }\end{array}$ & $\$ 100 \mathrm{~m}$ \\
\hline 5 & Yemen & Houthi & $\$ 100 \mathrm{~m}$ \\
\hline 6 & Afghanistan & Liwa Fatemiyoun & $\$ 2 \mathrm{~m}$ \\
\hline
\end{tabular}

Another factor that is the reason for the alliance between Iran and Houthi is the view of imperialism, especially against the US and Israel. To Iran, US efforts to exert influence in Iran have been going on for a long time. Before the Shah came to power, the US and Britain overthrew the prime minister, who eventually made the Shah the ruler and puppet of the United States. During the Shah's time, US influence was evident and dominant in Iran. ${ }^{7}$ Weakening relations between Iran and the US can be seen after the Iranian Revolution in 1979. The biggest US concern for Iran is a nuclear program that is being developed by the country with the most significant Shiite majority in the world. US concerns about Iran's nuclear are based on Iran's potential to prevent the US and Israel from dictating policies in the Middle East. As for the Houthis, anti-US slogans were also shouted in 2003. The anti-US slogans are precisely the same as the anti-US slogans that were echoed in Iran during the Iranian Revolution in 1979. This fact

${ }^{6}$ Ahmad ibn Abd al-Aziz Al-Hushain. Mausuat Madza Ta'rif an al-Firaq wa al-Madzahib. Riyadh: Dar Alim al-Kutub, 2007. p.

${ }^{7}$ Jalil Roshandel. Iran, Israel, and the United States. California: Praeger, 2011. p. 12 
is a reasonable thing considering that the uprising was conducted by Husein al-Houthi, inspired by the values of the Iranian Revolution.

Israel, which is a US ally, cannot be separated from the resistance carried out by Iran and Houthi. Relations between Iran and Israel have improved. However, relations between the two countries worsened with the election of Ahmadinejad as president in 2005. Ahmadinejad is a very anti-Israeli person, even though he also rejected the holocaust that caused millions of Jewish deaths. Not only that, the war between Israel and Iranian support groups, such as Hezbollah in 2006 and Hamas in 2008, further increased Iran's threat to Israel. On the other hand, Iran also views Israel as an obstacle to achieving the goals to be completed by Iran in the regional area.

Since the inauguration of Hassan Rouhani as president in 2013, Iran has sought to eliminate confrontations between the two countries through constructive dialogue and interaction. However, after the war in Gaza that occurred in 2014, Ali Khamenei declared that the first solution that must be carried out was gun resistance against Israel. Iran and Hamas relations are at least strengthened by several factors, including Hama's brutality in its action against the Palestinian people, even their lives are used as a shield. Second, for the first time, the Hamas attack on Israel did not get support from Arab countries, except Qatar. Third, Iran is the only country that protects Hamas. ${ }^{8}$

Wahhabism is another factor causing the close relations between Iran and Houthi. One of the main factors for the formation of this group was the Wahhabization movement that took place in Sa'adah, North Yemen. Initially, the Houthi's response was to dispel the wahhabization movement by establishing schools, as well as scientific meetings to revive the Zaidiyah spirit. Not only through education, but political channels also became one of the ways used by the Houthis by joining Husein al-Houthi in parliament from 1993 to 1997. It seems that the inexpensive method used by the Houthis to dispel Wahhabism was not very useful, which eventually forced the group to use other methods, namely the use of weapons and violence. The transformation that occurred in Houthi, which was initially a social movement into violent action, is considered a threat by the Yemeni government.

Iran's involvement in various conflicts in various countries by funding groups that are considered loyal and can be used as a proxy is inseparable from the national interests that Iran wants to achieve. Iran certainly also has the interest to be completed in Yemen by providing support to the Houthis, both in the form of funding, weapons, and military training. These interests can range from political, ideological, or economic interests. After the revolution, Iran strives to become a new superpower in the region. These goals are slowly being carried out with the mastery of several areas of the Middle East, such as Iraq, Syria, and Lebanon. Ali Riza Zakani, an Iranian member of parliament who also has close relations with Khamenei, stated that the three capital cities of the Arab countries, namely Beirut, Damascus, and Baghdad, were in the grip of Iran. ${ }^{9}$ The control of Yemen by the Houthis, which is an Iranian proxy, shows that Yemen is the fourth country in the region that has been successfully controlled by Iran.

Iran views Yemen, in general, and the northern region, which is predominantly inhabited by Shiites, in particular, as a convenient stage for conducting subversive activities against the Saudis, given that Yemen and the Saudis share border areas. Instability in Yemen can undoubtedly have an impact on Saudi security. This fact is what the Saudis are trying to prevent.

${ }^{8} \mathrm{M}$ Kiintzel. Iranian Antisemitism and the International Response. In R. S. Wistrich, Anti-Judaism, Antisemitism, and Delegitimizing Israel (pp. 242-254). Nebraska: University of Nebraska Press, 2016. p. 242

${ }^{9}$ Michael Segall. How Iran Views the Fall of Sana'a, Yemen: "The Fourth Arab Capital in Our Hands". Jerussalem Center for Public Affairs, 2014. Vol. 14 No. 36. 
Also, Iran views Yemen as an important factor in efforts to build a physical presence, both on land and at sea. If the Houthis succeed in controlling Bab al-Mandeb, then it will not only endanger countries loyal to the Saudis, such as Egypt and other Gulf states, but also European countries along the Mediterranean Sea. ${ }^{10}$

Another interest to be achieved is the interests of ideology. According to the opinion of the writer, the ideological interests to be completed by Iran in Yemen are divided into two, namely the interests of spreading the ideology of Iran's Islamic Revolution and Shiite ideology. The spread of revolutionary ideology and Shiite ideology has been Iran's foreign policy since the revolution in 1979. The following will be discussed how Iran's efforts in spreading these two ideologies in Yemen.

Concerning the spread of Shi'ite ideology, in the case of Yemen, efforts to spread the Shiite ideology of Imamiyah have been carried out since the 1990s when the Iranian government gave scholarships to Yemeni youths to continue their studies at Iranian universities. Not only that, but the Iranian embassy in Yemen also enrolled Yemeni children in junior and senior high schools at several Iranian-owned educational institutions in Sana'a and Sa'adah. Besides, Iran also seeks to build relations with Shiite Zaidiyah groups through various activities such as inviting delegates from this group to attend conferences, commemorative events of the Iranian Revolution, and other cultural and political activities. ${ }^{11}$ Iran's efforts appear to be bearing fruit, although not so significantly. This fact can be proven by the arrest of several people who converted to become Imami Shi'ites by the Yemeni government in $2009 .{ }^{12}$

Table 3. Iran's Institutions in Yemen

\begin{tabular}{lll}
\hline No & Institutions & Location \\
\hline 1 & The Supreme Dar Al Uloom & Aden \\
2 & Ja'fariyah School & Aden \\
3 & The Badr Al Ilmi Center & Sana'a \\
4 & The Center for Islamic Studies & Sana'a \\
5 & Al Hadi School & Sa'dah \\
6 & The Thaqlim Center & Sana'a \\
7 & Dahyan Center & Sa'dah \\
8 & Dar Al Zahra Cultural Media Foundation & Sana'a \\
9 & The Yemeni Islamic Shiite Council & Taiz \\
10 & Dar Ahbab Ahl Al Bait & Taiz \\
11 & Naba'a Charitable Foundation & Jawf \\
12 & Ali Asghar Ibn Hussain Society & Jawf \\
\hline
\end{tabular}

The data in the table above shows some of Iran's institutions in Yemen. Among these institutions, the most famous is the Dar al-Zahra Cultural Media Foundation. Among its movements are the empowerment of Muslim women, the conscious spread of Islam based on the correct understanding of Islam, according to Ahlu al-Bait, the establishment of special

\footnotetext{
${ }^{10}$ Ibid, Op. cit

${ }^{11}$ Mohammad Hassan Al-Qadhi. The Iranian Role in Yemen and Its Implications on the Regional Security. Cairo: Arabian Gulf Centre for Iranian Studies, 2017. p. 26

${ }_{12}$ Nir Rosen. Yemen's Shia Dillema. Retrieved from Aljazeera: https://www.aljazeera.com/indepth/opinion/2011/05/201152483619116456.html May 24, 2011
} 
libraries about women, and so on. This institution also has many branches spread across all provinces in Yemen, including Ja'fariyah School, The Yemeni Islamic Shiite Council, Naba'a Charitable Foundation, and so forth. Besides, several Shiite Imamiyah people or those who were influenced by the values of the Iranian Islamic Revolution led several schools and mosques, including The Badr al-Ilmi Center, The Center for Islamic Studies, The Supreme Dar al-Uloom, and etcetera. These institutions are indeed engaged in various fields, such as education, publications, media, humanitarian organizations, fundraising, and so forth. Although the movements are diverse, the main objective to be achieved with the establishment of these institutions is to carry the mission of spreading Imamiyah Shiite teachings.

Although Iran is currently more pragmatic in its efforts to determine its foreign policy by prioritizing political interests rather than ideology, identity and ideology are still an essential part of efforts to assess Iran's foreign policy since 1979. According to several sources, Major General Qassem Soleimani, IRGC commander, is the person behind the attempt to re-create the Persian and Shia kingdoms in Arab lands. ${ }^{13}$ At present, to spread Shi'ite teachings, Iran tends to use diplomatic methods through embassies in various countries such as in Ghana, Senegal, Morocco, and several other countries. ${ }^{14}$

According to data compiled by the Pew Research Center in 2011, Shiites are spread across several regions of the Middle East, with Iran being the region with the most Shiite population in the world. Like the Sunnis, the Shiites also have diverse schools. Shia Imamiyah is the most dominant school compared to other schools such as Ismaili, Zaidiyah, Alawiyah, and Druze. These streams differ geographically, linguistically, politically, and ideologically. ${ }^{15}$ However, at present, Iran is more pragmatic by ruling out differences in flow and ideology to achieve political interests. This fact can be seen from the alliances established by Iran, some of which are Sunni groups, such as Hamas and Islamic Jihad. Even so, the support given by Iran to these groups is undoubtedly different. Loyalty and ideological similarity remain determinants of the amount of support Iran provides to these groups.

Iran's involvement in the conflict in Yemen is to improve the economic situation in Iran, especially after the economic sanctions imposed by the US on Iranian oil sales. The negative impact of the economic sanctions imposed by the US on the Iranian economy includes a significant decline in the value of Iran's oil exports. Regarding Yemen, this country is less important to Iran than the Saudis. Geographically, Saudi borders Yemen. Instability in Yemen can jeopardize Saudi security. This fact is not the case with Iran, which does not have a direct border with Yemen. Besides, as has been widely discussed, Iran's limited support for Houthis has an impact on the limited profits achieved by Iran in Yemen. Iran has indicated no influence over the policies adopted by the Houthis. Compared to the Saudis, who supported the Yemeni government in an attempt to destroy Houthi. The Saudis are also suspected of providing financial support to tribal groups that oppose the Houthis. ${ }^{16}$ Support provided by the Saudis is relatively reasonable, considering that Houthis will remain the dominant group in Yemen without Iranian assistance, while Hadi will further weaken without Saudi assistance.

\footnotetext{
${ }^{13}$ Samia Nakhoul. Iran Expands Regional 'Empire' ahead of Nuclear Deal. Retrieved from Reuters: https://www.reuters.com/article/us-mideast-iran-region-insight/iran-expands-regional-empire-ahead-ofnuclear-deal-idUSKBNOMJ1G520150323 March 23, 2015

${ }^{14}$ Mohammed Hashiru, M. (2017). The Iranian Diplomatic Mission and the Spread of Shiism in Ghana. International Journal of Sciences: Basic and Applied Research, 2017. Vol. 34 No. 3. p. 253

15 Kamran Bokhari. Why Shiite Expansion will be Short-Lived. Retrieved from Stratfor: https://worldview.stratfor.com/article/why-shiite-expansion-will-be-short-lived May 12, 2015

${ }^{16}$ Thomas Juneau. Iran's Policy Towards the Houthis in Yemen: A Limited Return in a Modest Investment. International Affairs, 2016. Vol. 92 No. 3, p. 663
} 
US and Iran's relations had improved when economic sanctions against Iran were lifted. However, this did not last long. The US has again imposed sanctions on Iran by stopping oil trade with Iran. Besides, although the US has also revoked the easing of eight countries to buy oil from Iran in April 2018, five of the eight countries given the exception until mid-2019 are still making purchases of Iranian oil. This fact shows that basically, Iran will always be able to survive with the results of oil sales to several countries. However, the amount is not so significant when compared to the years when these economic sanctions have not been implemented. Besides, with the continued occurrence of Iranian oil trade, it also shows that US efforts to suppress Iranian oil sales to the lowest point have not been successful.

However, if Iran manages to gain control of Yemen and the strategic regions which are the center of world trade, this strategic position can at least be used by Iran to help the economy, which is currently affected by economic sanctions. As such, Iran's economic interests in Yemen are virtually insignificant compared to political and ideological interests. Economic interests will only be achieved if Iran manages to gain control of Yemen, both directly and through the Houthis.

\section{Conclusion}

Of the several dominant groups in Yemen, Iran prefers Houthis as an alliance as well as a proxy to involve itself in the Yemen conflict. Based on the theory of constructivism used by the author, there are several factors that attract Iran to establish relations with Houthis. These factors include Shi'ism, anti-imperialism, which provides for anti-US and anti-Israel, and its allies, and anti-Wahhabism. According to the author's analysis, the element of pleasure has a significant role in the totality of support provided by Iran.

As noted, in addition to providing support and assistance to Shiite groups, Iran also provides support to Sunni groups such as Hamas and Islamic Jihad in Palestine. This relation is based on the ideology similarity of Hamas and Iran, which is anti against the US and Israel. In the case of Yemen, although AQAP and ISIS are a counter-group to the US and Israel, Houthis have more potential to be made as an alliance and proxy. This fact is because Houthi has a factor that is not possessed by AQAP and ISIS, namely sadism. However, when compared to Hezbollah, Iran's support and assistance to Houthis are still limited, because although Shia is both Houthis, they do not recognize Wilayat al-Faqih as a system and concept of leadership as Hezbollah acknowledges. This fact explains why Iran is very totalistic in its efforts to provide support to Hezbollah.

Iran's involvement in the conflict is not without reason. There are several motives that the authors find related to Iran's involvement and its alliance with the Houthis in the conflict. Among the ambitions most frequently reviewed in many studies is the aim to rebuild the Persian Kingdom that once triumphed. However, the possibility to realize that ambition is tiny. At least, the goal to be achieved by Iran, especially after the 1979 revolution, is to become a new superpower in the Middle East by spreading the values of the revolution there. In the case of Yemen, Iran sees that this country has potential as an object of instilling the benefits of the Islamic revolution by using Houthis as an intermediary.

Besides, to spread the value of revolution, Iran is also trying to spread the Shiite sect in Yemen. Although this is a challenge for Iran, considering that the Shiite adopted by the Yemeni community is the Zaidi Shiite, which has some fundamental differences from the Shiite Imamiyah. Nevertheless, Iran's efforts in spreading Imamiyah teachings can be seen by the 
establishment of various Iranian-owned institutions which are engaged in multiple fields, such as education, publications, media, humanitarian organizations, and so forth. Although the movements are diverse, the main objective is to carry out the mission of spreading Imamiyah Shiite teachings.

In addition to political and ideological interests, both Iran and Houthi also have economic interests. For Iran, economic interests in Yemen are not a top priority. Despite Yemen's very strategic location, Iran's efforts to realize economic interests in Yemen will be complicated to do. On the other hand, for Houthis, economic interests are in contact with political problems. Houthis will easily control the economy if this group indeed manages to control Yemen in total. However, the Houthis are currently able to control several areas that are a source of income for them.

\section{References}

[1] Albloshi, H. H. (2016). Ideological Roots of the Huthi Movement in Yemen. Journal of Arabian Stuides, 6(2), 143-162.

[2] Al-Qadhi, M. H. (2017). The Iranian Role in Yemen and Its Implications on the Regional Security. Cairo: Arabian Gulf Centre for Iranian Studies.

[3] Bokhari, K. (2015, May 12). Why Shiite Expansion will be Short-Lived. Retrieved from Stratfor: https://worldview.stratfor.com/article/why-shiite-expansion-will-be-short-lived

[4] Clausen, M.-L. (2015). Understanding the Crisis in Yemen : Evaluatin Competing Narratives. Italian Journal of International Affairs, 16-29.

[5] Freeman, J. (2009). The al Houthi Insurgency in the North of Yemen: An Analysis of the Shabab al Moumineen. Studies in Conflict and Terrorism, 1008-1019.

[6] Hashiru, M. (2017). The Iranian Diplomatic Mission and the Spread of Shiism in Ghana. International Journal of Sciences: Basic and Applied Research, 34(3), 247-261.

[7] Jackson, R., \& George Sorensen. (2014). Pengantar Studi Hubungan Internasional. (D. Suryadipura, \& Pancasari Suyatiman, Trans.) Yogyakarta: Pustaka Pelajar.

[8] Juneau, T. (2016). Iran's Policy Towards the Houthis in Yemen: A Limited Return in a Modest Investment. International Affairs, 92(3), 647-663.

[9] Kiintzel, M. (2016). Iranian Antisemitism and the International Response. In R. S. Wistrich, Anti-Judaism, Antisemitism, and Delegitimizing Israel (pp. 242-254). Nebraska: University of Nebraska Press.

[10] KSA, E. o. (2016, November 9). Saudi Arabia Condems Ongoing Iranian Regional Interference and Agression. Retrieved from Embassy of KSA: http://ksaembassy.be/en/saudi-arabia-condemnsongoing-iranian-regional-interference-aggression/

[11] Nakhoul, S. (2015, March 23). Iran Expands Regional 'Empire' ahead of Nuclear Deal. Retrieved from Reuters: https://www.reuters.com/article/us-mideast-iran-region-insight/iran-expandsregional-empire-ahead-of-nuclear-deal-idUSKBNOMJ1G520150323

[12] Ram, H. (2007). Exporting Iran's Islamic Revolution: Steering a Path between Pan-Islamism and Nationalism. Terrorism and Political Violence, 7-24.

[13] Rosen, N. (2011, May 24). Yemen's Shia Dillema. Retrieved from Aljazeera: https://www.aljazeera.com/indepth/opinion/2011/05/201152483619116456.html

[14] Roshandel, J. (2011). Iran, Israel, and the United States. California: Praeger.

[15] Segall, M. (2014). How Iran Views the Fall of Sana'a, Yemen: "The Fourth Arab Capital in Our Hands". Jerussalem Center for Public Affairs, 14(36).

[16] Tilly, C., \& Sidney Tarrow. (2015). Contentious Politics. New York: Oxford University Press. [17] Wendt, A. (1992). Anarchy is What States Make of it: The Social Construction of Power Politics. International Organization, 46(2), 391-425. 